\title{
Investigations of Cuprous Oxide and Cupric Oxide Thin Films by Controlling the Deposition Atmosphere in the Reactive Sputtering Method
}

\author{
Jinyan Pan, Chengfu Yang, ${ }^{1}$ and Yunlong Gao ${ }^{2 *}$ \\ School of Information Engineering, Jimei University, Xiamen, Fujian 361021, China \\ ${ }^{1}$ Department of Chemical and Materials Engineering, National University of Kaohsiung, Kaohsiung 811, Taiwan \\ ${ }^{2}$ School of Information Science and Engineering, Xiamen University, Xiamen, Fujian 361005, China
}

(Received August 31, 2015; accepted May 12, 2016)

Keywords: $\mathrm{Cu}_{2} \mathrm{O}$ thin films, light absorption layer, optical band-gap

$\mathrm{Cu}_{2} \mathrm{O}$ is a direct and narrow band-gap material; hence, it serves as an important candidate material for applications such as solar cells. In this study, copper $(\mathrm{Cu})$ metal was used as a target and the reactive sputtering method was used to deposit cuprous oxide $\left(\mathrm{Cu}_{2} \mathrm{O}\right)$ and cupric oxide $(\mathrm{CuO})$ thin films on indium tin oxide (ITO) glass. The formation of $\mathrm{Cu}_{2} \mathrm{O}$ and $\mathrm{CuO}$ thin films was controlled by varying oxidation conditions, such as controlling the deposition atmosphere (called the $\mathrm{O}_{2}$ ratio). The microstructure, crystalline orientation, and optical properties of $\mathrm{Cu}_{2} \mathrm{O}$ and $\mathrm{CuO}$ thin films were measured using $\mathrm{X}$-ray diffraction and optical spectroscopy, respectively. The results for the deposited thin films indicated that the formation of thin films as $\mathrm{Cu}_{2} \mathrm{O}$ and $\mathrm{CuO}$ phases was controlled by the flow rate of oxygen during the deposition process. In addition, the $(\alpha h v)^{n}-h v$ curve plot was used to find the optical energy band gap of the $\mathrm{Cu}_{2} \mathrm{O}$ and $\mathrm{CuO}$ thin films. Moreover, we found that the crystalline phase and morphology of the deposited thin films affected the properties of the spectral response. This study provides a reference for the possible exploration and application of new, high-performance thin-film photovoltaic solar cells.

\section{Introduction}

Problems related to the energy and environment are becoming increasingly serious, and with increasingly strong demands for new energy sources, solar cells are the most direct approach for achieving a clean solar energy utilization. Hence, the development of new photovoltaic materials plays a significant role in promoting a sustainable development of the world. ${ }^{(1-5)}$ The future development of silicon-based photovoltaic cells is hampered by the present cost of materials and fabrication. In this work, cuprous oxide $\left(\mathrm{Cu}_{2} \mathrm{O}\right)$ and cupric oxide $(\mathrm{CuO})$ thin films were studied as low-cost photovoltaic power generation for the following reasons: (i) The solar cells' conversion efficiency can theoretically reach $18 \%{ }^{(6)}$ (ii) They are nontoxic materials and their preparation process is harmless. (iii) The raw materials for making $\mathrm{Cu}_{2} \mathrm{O}$ and $\mathrm{CuO}$ thin films are readily available and the oldest semiconducting materials known to solid-state physicists, and using them to fabricate solar cells will be low-cost;(7) (iv) The preparation process for photovoltaic thin films is easy and simple. ${ }^{(8-12)} \mathrm{CuO}$ is also an interesting candidate for application to solar energy conversion

*Corresponding author: e-mail: gaoyl@xmu.edu.cn 
devices, superconducting devices, ${ }^{(13)}$ gas sensors, ${ }^{(14)}$ and material sensors. ${ }^{(15-18)}$

$\mathrm{CuO}$ (monoclinic) is reported to possess n-type conductivity with band-gap values ( $E_{\mathrm{g}}$ values) of 1.9-2.1. $\mathrm{Cu}_{2} \mathrm{O}$ (cubic) is typical of the oldest p-type semiconducting materials with $E_{\mathrm{g}}$ values of 2.1-2.5 eV. ${ }^{(19-22)}$ It is capable of absorbing most of solar energy and is useful in solar cell applications. The formation of a $\mathrm{Cu}$ vacancy is an often-stated mechanism to describe the origin of p-type conductivity in $\mathrm{Cu}_{2} \mathrm{O}$. So far, many different techniques for the fabrication of crystalline copper oxide thin films have been proposed. For example, electrochemical deposition, which is an expensive technique, requires special conditions and usually results in mixed phases with special structures, for example, $\mathrm{Cu}_{2} \mathrm{O} / \mathrm{CuO} / \mathrm{Co}_{3} \mathrm{O}_{4}$ core-shell nanowires. ${ }^{(10)}$ Muthe et al. used an electronbeam heated source as a deposition technique and $\mathrm{Cu}_{2} \mathrm{O}$ thin films could be grown with relative ease by maintaining the atomic oxygen flux at 1.6 times the stoichiometric value. ${ }^{(8)}$ Thermal oxidation is a simple and low-cost technique to prepare copper oxide thin films with different crystalline phases. ${ }^{(11,20)}$ Siripala et al. found that annealing below $300{ }^{\circ} \mathrm{C}$ enhanced the n-type photocurrent produced by the junction. ${ }^{(19)}$ However, the highest conversion efficiency using $\mathrm{Cu}_{2} \mathrm{O}$ solar cells to date is below 4\%.(12) There are still obstacles that limit the use of copper oxide in nanoelectronics, mainly because (i) the single band gap of single-phase copper oxide films commonly limits light absorption, and (ii) thermal oxidation easily induces a high resistance.

However, sputtering is known to provide thin films that are highly uniform physically for use in semiconductor development and many research fields. It is simple to deposit thin films with a controllable thickness by changing the deposition time and with a controllable crystalline phase by changing the deposition atmosphere and temperature. For these reasons, we used sputtering with a $\mathrm{Cu}$ target to deposit $\mathrm{Cu}_{2} \mathrm{O}$ and $\mathrm{CuO}$ thin films. From previous studies, we found that the temperature and oxygen flow rate during sputtering are two important factors affecting the crystalline phase and properties of deposited copper oxide thin films. In this study, we used reactive sputtering to achieve copper oxides and to investigate the phase formation, crystallization, and energy band gap of the different types of copper oxides by controlling process parameters. We used a simple method of controlling the $\mathrm{O}_{2}$ ratio during the deposition to partially oxidize $\mathrm{Cu}$ metal and form either $\mathrm{Cu}_{2} \mathrm{O}$ or $\mathrm{CuO}$ thin films by physical deposition on ITO substrates. The partial or full oxidation of $\mathrm{Cu}$ metal at temperatures below $300{ }^{\circ} \mathrm{C}$ was examined and its effect on the reaction of $\mathrm{O}_{2}$ ratio and the effect of deposition temperature on the selectivity of metal oxidation were studied.

\section{Experimental Methods}

Indium tin oxide (ITO) was used as the substrate. An area of $2 \times 2 \mathrm{~cm}^{2}$ was cleaned ultrasonically with acetone and deionized (DI) water and then dried under blown nitrogen gas. Magnetron sputtering was used to prepare the $\mathrm{Cu}_{2} \mathrm{O}$ or $\mathrm{CuO}$ thin films by controlling the ratio of $\mathrm{O}_{2} /$ $\mathrm{Ar}$ in the gas flow. A metal copper sputtering target of $99.999 \%$ purity was employed as a target, the base pressure of the sputtering chamber was below $6.0 \times 10^{-4} \mathrm{~Pa}$, and the working pressure was maintained at 0.4 Pa. During the deposition process, high-purity argon (Ar, 99.999\%) at a flow rate of $40 \mathrm{sccm}$ was used as the background gas, and the deposition time ranged from 15 to $90 \mathrm{~min}$. By changing flux ratios of $\mathrm{O}_{2} / \mathrm{Ar}$ from 1:16 to 1:2, different copper oxides could be created via reactive magnetron sputtering. To further improve the quality of the thin films, heat treatments were used to anneal the deposited thin film and the annealing temperature was $300^{\circ} \mathrm{C}$ and the annealing time was 10 min in $\mathrm{N}_{2}$ atmosphere. 
To analyze the crystalline phase of the prepared thin films, their crystalline structures were determined using X-ray diffraction (XRD, D8 Advance, Germany, Bruker) patterns with $\mathrm{Cu} \mathrm{K} \alpha$ radiation $(\lambda=1.5418 \AA)$. The thickness and surface morphology of the deposited thin films were observed using field emission scanning electron microscopy (FESEM, SU70, Japan, Hitachi). The optical transmission spectrum was recorded in the 400-900 nm wavelength range using a UV/VIS spectrophotometer (UV-2550, Japan, Shimadzu Corporation).

\section{Results and Discussion}

When sputtering is used to excite $\mathrm{Cu}$ particles at a fixed power, we believe that the flow ratio of oxygen/argon affects the composition of the copper oxide thin films in the reactive sputtering process. When the deposition power was $70 \mathrm{~W}$ for a deposition time of $30 \mathrm{~min}$, as the flow ratio of $\mathrm{O}_{2}$ was changed, copper oxide thin films with different crystalline structure were really produced, as shown in the XRD patterns in Fig. 1. When the $\mathrm{O}_{2}$ :Ar ratio was 1:16, two diffraction peaks appeared at 36.5 and $42.4^{\circ}$, which correspond well to diffraction peaks of (111) and (200) for the $\mathrm{Cu}_{2} \mathrm{O}$ phase, and a stronger (111) orientation was observed. The $\mathrm{Cu}$ and $\mathrm{CuO}$ phases were not observed in the XRD pattern. When the $\mathrm{O}_{2}$ :Ar ratio was $1: 2$, the diffraction peaks of $\mathrm{Cu}_{2} \mathrm{O}$ phase vanished, while new diffraction peaks appeared at 35.5 and $38.7^{\circ}$, which correspond well to diffraction peaks of (002) and (111) for the $\mathrm{CuO}$ phase.

The surface morphologies of $\mathrm{Cu}_{2} \mathrm{O}$ and $\mathrm{CuO}$ thin films observed by SEM are shown in Fig 2. The crystalline phases shown in Fig. 1 suggest that the variation of the composition of the copper oxides is primarily determined by the $\mathrm{O}_{2}$ flow ratio in reactive magnetron sputtering, after which the phase was determined. According to XRD results, if the $\mathrm{O}_{2}$ :Ar ratio is $1: 16$ or 1:2, the $\mathrm{Cu}_{2} \mathrm{O}$ or single $\mathrm{CuO}$ phase would be created, respectively. These results suggest that the $\mathrm{O}_{2}$ flow ratio affects the phase of deposited copper oxide thin films and also their surface morphologies. Figure 2 shows the observations of the surfaces of copper oxide thin films with various $\mathrm{O}_{2}$ ratios in the deposition atmosphere. As shown in Fig. 2(a), a high-resolution SEM image of a $\mathrm{Cu}_{2} \mathrm{O}$ thin film revealed that a densified surface morphology, consisting of nanocrystalline particles, was formed. Figure 2(a) also shows that, when $\mathrm{O}_{2}$ :Ar ratio was $1: 16$, the growth of the $\mathrm{Cu}_{2} \mathrm{O}$ thin film was smooth and uniform, and no impurities were observed. The particle sizes of nanocrystalline grains were between 30 and $60 \mathrm{~nm}$. We believe that the deposition process causes the $\mathrm{Cu}$ atoms to have enough

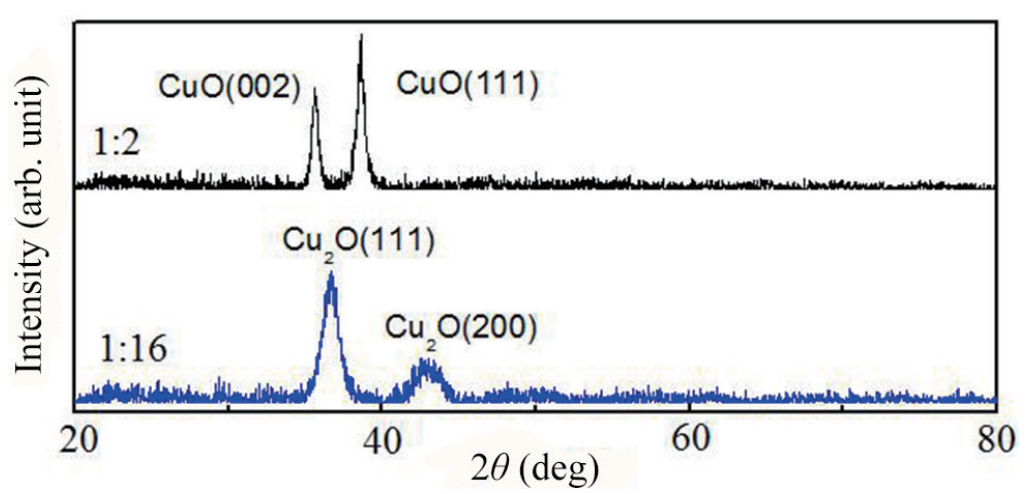

Fig. 1. (Color online) XRD patterns of deposited copper oxide thin films under different $\mathrm{O}_{2}$ flow ratios; $\mathrm{O}_{2}$ : $\mathrm{Ar}$ ratios were $1: 16$ and $1: 2$. 


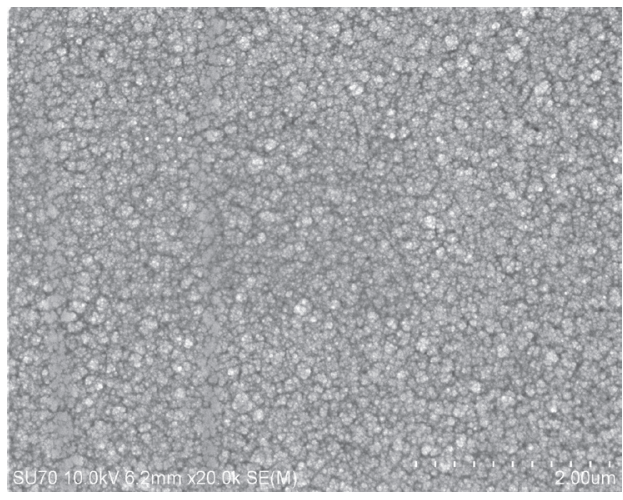

(a)

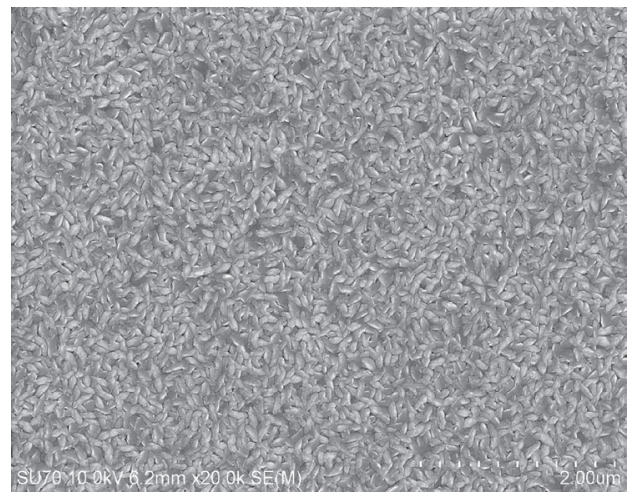

(b)

Fig. 2. Microscopic morphologies of (a) $\mathrm{Cu}_{2} \mathrm{O}$ and (b) $\mathrm{CuO}$.

activation energy so that the $\mathrm{Cu}_{2} \mathrm{O}$ thin films have a higher densification, a larger particle size, and a greater roughness. By comparing the results in Fig. 2(a) with those in Fig. 2(b), the surface morphology of $\mathrm{CuO}$ thin films was considered different from that of $\mathrm{Cu}_{2} \mathrm{O}$ thin films. Figure 2(b) shows that, when $\mathrm{O}_{2}$ :Ar ratio was $1: 2$, the growth of $\mathrm{CuO}$ thin films resulted in a densified surface morphology, consisting of ellipse-shaped or spiral-shell nanocrystalline particles with a randomly oriented morphology. Figure 2(b) shows that $\mathrm{CuO}$ particles ranged in nanometer from 20 to 100 and the grain boundaries were observed.

Annealing was carried out at $300{ }^{\circ} \mathrm{C}$ to treat the as-deposited $\mathrm{Cu}_{2} \mathrm{O}$ and $\mathrm{CuO}$ thin films to improve their characteristics. To investigate the heat treatment of the films, microscopic morphologies of $\mathrm{Cu}_{2} \mathrm{O}$ and $\mathrm{CuO}$ thin films after annealing treatment are shown in Fig. 3. It can be seen from Fig. 3(a) that, after heat treatment, the morphology of the $\mathrm{Cu}_{2} \mathrm{O}$ thin film changed, the grain sizes of nanocrystalline $\mathrm{Cu}_{2} \mathrm{O}$ particles increased, and the grain boundary gradually blurred. By comparing the results in Figs. 2(b) and 3(b), the grain size of nanocrystalline $\mathrm{CuO}$ particles was observed to increase by about $30 \mathrm{~nm}$, and the grain boundary was observed to become fuzzy. Therefore, annealing improves the quality of $\mathrm{Cu}_{2} \mathrm{O}$ and $\mathrm{CuO}$ thin films, and that will have a direct impact on the photoelectric properties of $\mathrm{Cu}_{2} \mathrm{O}$ and $\mathrm{CuO}$ thin films.

A comparison of the SEM shown in Figs. 2(a) and 3(a) clearly indicates that annealing influences the surface morphologies of the crystalline structure of $\mathrm{Cu}_{2} \mathrm{O}$ thin films. XRD patterns of as-deposited and annealed $\mathrm{Cu}_{2} \mathrm{O}$ thin films are compared in Fig. 4(a). The results in Fig. 4(a) show that diffraction intensities of the (111) phase at $2 \theta=36.5^{\circ}$ and the (200) phase at $2 \theta=42.9^{\circ}$ were enhanced. Compared with the results in Fig. 4(a), the full-width at half-maximum (FWHM) of the (111) diffraction peak of the $\mathrm{Cu}_{2} \mathrm{O}$ phase decreased when the annealing process was used. The increase in diffraction intensity and the decrease in FWHM are attributed to the grain growth of nanocrystalline particles, as seen in the surface morphologies in Figs. 2(a) and 3(a). In addition to the (111) and (200) phases, there are the other phases: phase (200) at $29.5^{\circ}$, phase (220) at $42.3^{\circ}$, phase (222) at $51.2^{\circ}$, phase (220) at $61.5^{\circ}$, and phase (311) at $74.3^{\circ}$, which are weak peaks. These results suggest that the crystallization of $\mathrm{Cu}_{2} \mathrm{O}$ thin films is improved by annealing. Figure 4(b) shows the $\mathrm{CuO}$ thin films before and after annealing. For $\mathrm{CuO}$ thin films, these results reveal that the growth orientation was almost unchanged and the diffraction intensities of the (002) and (111) phases had not been enhanced. These results suggest that $\mathrm{CuO}$ is a more stable thin film. 


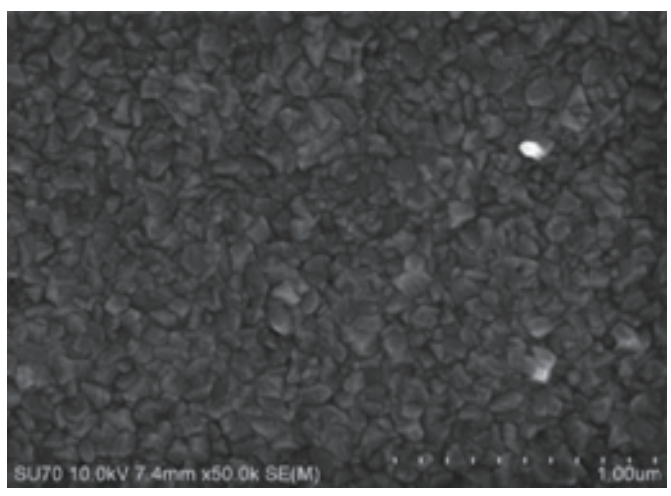

(a)

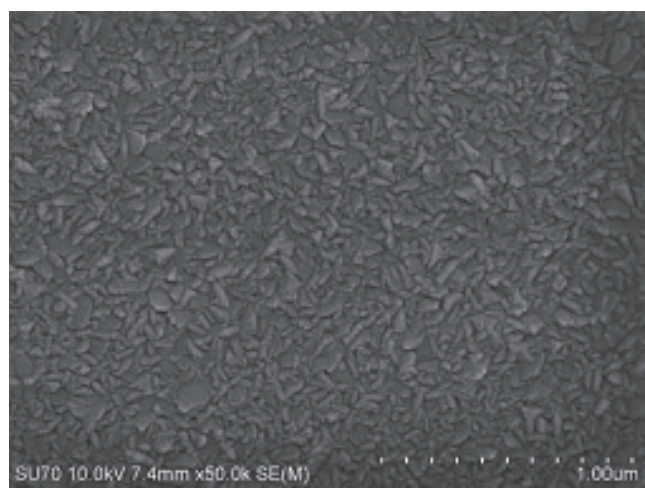

(b)

Fig. 3. Surface morphologies of $300{ }^{\circ} \mathrm{C}$-treated thin films: (a) $\mathrm{Cu}_{2} \mathrm{O}$ and (b) $\mathrm{CuO}$.

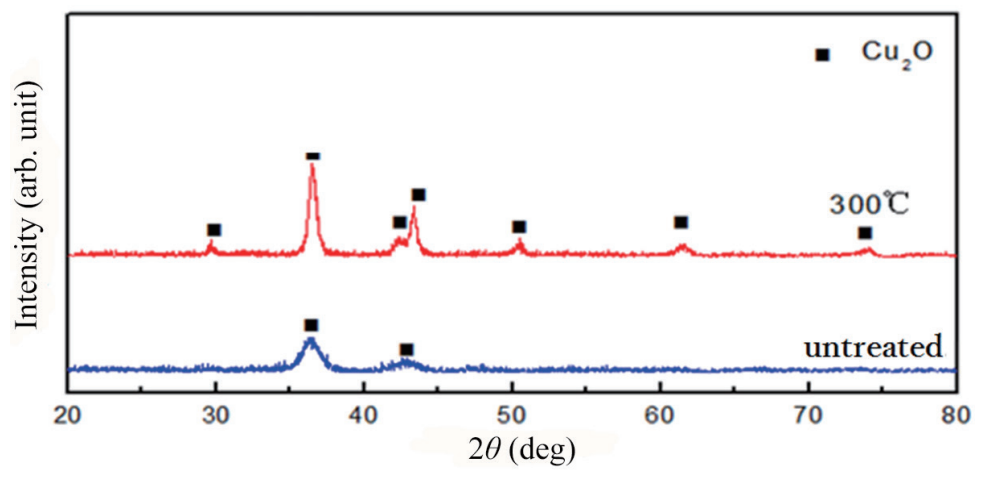

(a)

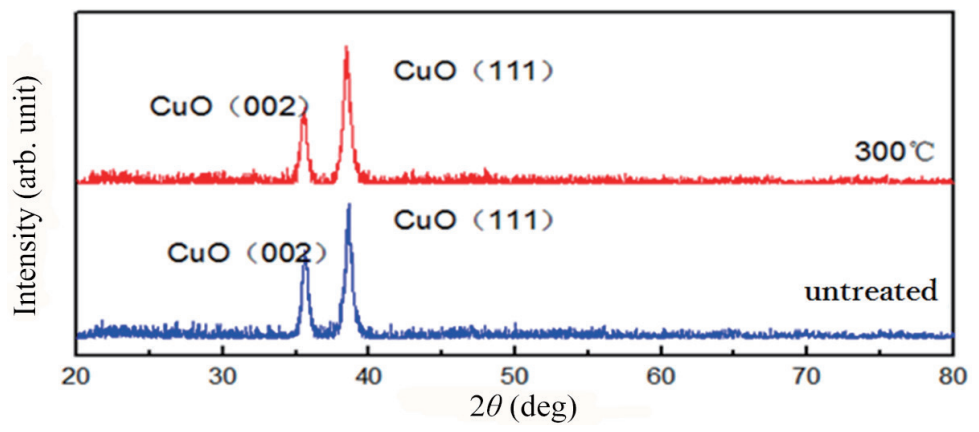

(b)

Fig. 4. (Color online) XRD patterns of (a) $\mathrm{Cu}_{2} \mathrm{O}$ and (b) $\mathrm{CuO}$ thin films.

Figure 5 shows the absorption spectrum of $300{ }^{\circ} \mathrm{C}$-annealed $\mathrm{Cu}_{2} \mathrm{O}$ thin films plotted against wavelength in the region of 400-900 nm. From the absorption spectrum in Fig. 5, it can be seen that $\mathrm{Cu}_{2} \mathrm{O}$ thin films had a critical absorption edge in the wavelength range around $400 \mathrm{~nm}$. They also had good absorption in the wavelength range of $400-570 \mathrm{~nm}$ and a very strong absorption edge appearing at a wavelength of around $570 \mathrm{~nm}$. Figure 6 shows the absorption spectrum of $\mathrm{CuO}$ thin films plotted against wavelength in the region of 500-900 nm. It can be seen that the absorption of 


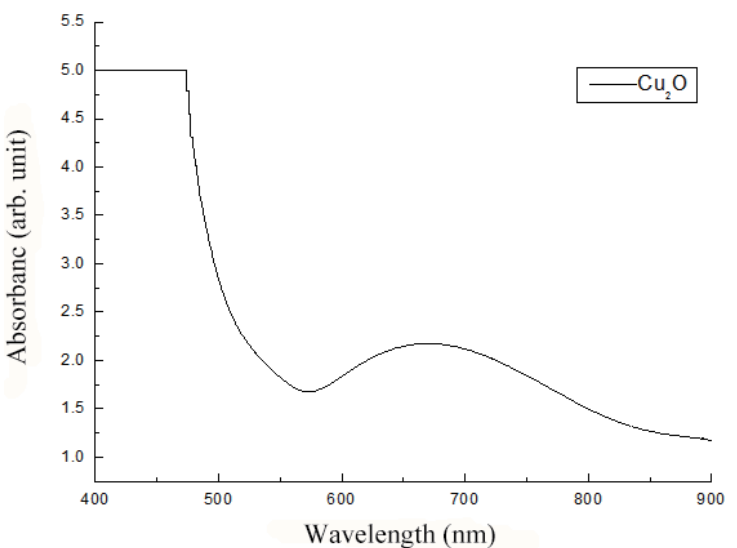

Fig. 5. UV Vis absorption spectrum of $\mathrm{Cu}_{2} \mathrm{O}$ film.

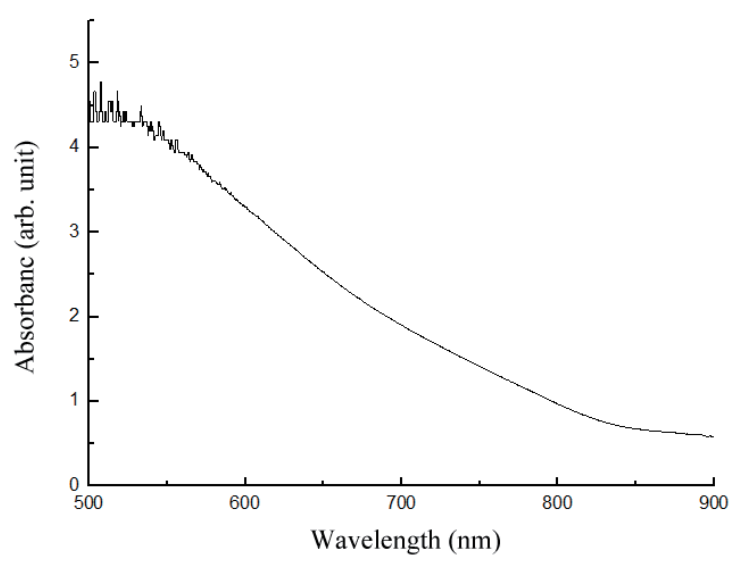

Fig. 6. UV Vis absorption spectrum of $\mathrm{CuO}$ film.

$\mathrm{CuO}$ thin films decreases linearly in the wavelength range from 500 to $800 \mathrm{~nm}$, and the $\mathrm{CuO}$ thin films had a large absorption at wavelengths in the near-IR range. These results suggest that $\mathrm{Cu}_{2} \mathrm{O}$ and $\mathrm{CuO}$ thin films are candidates for solar-cell devices and $\mathrm{CuO}$ thin films are a candidate for nearIR detectors.

Figure 7 shows the absorbance spectra of $\mathrm{CuO}$ thin films as a function of annealing temperature. The results in Fig. 7 show that the absorbance of $\mathrm{CuO}$ thin films increased as the annealing temperature increased from 300 to $400{ }^{\circ} \mathrm{C}$, especially for wavelengths of light between 500 and 800 $\mathrm{nm}$. The reason is that, when the annealing temperature increased, the grain size of $\mathrm{CuO}$ thin films increased, which not only roughened the thin film surface and enhanced the scattering of light but also weakened the transmission of $\mathrm{CuO}$ thin films.

Previously, the determination of the optical energy band gap $\left(E_{\mathrm{g}}\right)$ was often necessary to develop the electronic band structure of a thin-film material. A Tauc plot is one method of determining the optical band gap in semiconductors. However, when the Tauc plot is used, the $E_{\mathrm{g}}$ of thin films is extracted from the data of absorption coefficient as a function of photon energy $(h v)$. The $E_{\mathrm{g}}$ of the thin films can be determined as

$$
(\alpha h v)^{n}=A\left(h v-E_{\mathrm{g}}\right)
$$

where $\alpha$ is the optical absorption coefficient, which is proportional to absorbance, $h v$ is the energy of the photon, $A$ is a constant, and $E_{\mathrm{g}}$ is the optical band gap. Both $\mathrm{CuO}$ and $\mathrm{Cu}_{2} \mathrm{O}$ are direct-bandgap semiconductors, and $E_{\mathrm{g}}$ can be obtained from Eq. (1). From the absorption spectra, we can obtain the $(\alpha h v)^{n}-\mathrm{h} v$ curve plot, and the linear relationship of the absorption edge is extended to the energy axis. $E_{\mathrm{g}}$ can be determined by extrapolating a straight line at $\alpha h v=0$, from which the $E_{\mathrm{g}}$ of the copper oxide can be obtained. The linearity of $(\alpha h v)^{n}$ indicates that $\mathrm{Cu}_{2} \mathrm{O}$ thin films are direct transition semiconductors, for which $n=2$. As calculated from the results in Fig. 5, the $E_{\mathrm{g}}$ of $\mathrm{Cu}_{2} \mathrm{O}$ thin film band-gap width is $2.4 \mathrm{eV}$. In general, the $E_{\mathrm{g}}$ of $\mathrm{Cu}_{2} \mathrm{O}$ thin films is generally greater than that of $\mathrm{Cu}_{2} \mathrm{O}$ bulk materials, and different preparation processes and parameters lead to differences in band gap. ${ }^{(14-17)}$ It is known that the $E_{\mathrm{g}}$ of $\mathrm{Cu}_{2} \mathrm{O}$ bulk materials ranges from 2.0 to $2.5 \mathrm{eV}$. The 


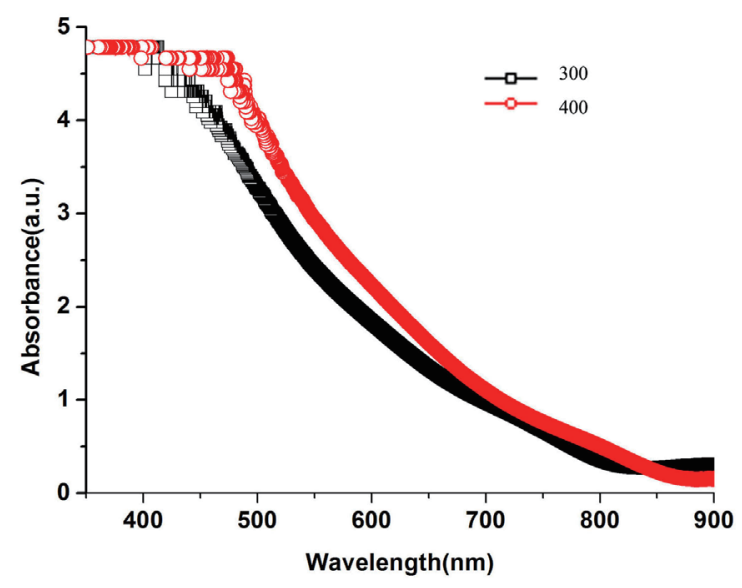

Fig. 7. (Color online) Absorbance of $\mathrm{CuO}$ at a function of the temperature.

difference in $E_{\mathrm{g}}$ between $\mathrm{Cu}_{2} \mathrm{O}$ thin films investigated in this study and reported in the literature is mainly caused by the quantum size effect in $\mathrm{Cu}_{2} \mathrm{O}$ thin films. As calculated from the results in Fig. 6, the $E_{\mathrm{g}}$ of $\mathrm{CuO}$ thin films is about $1.9 \mathrm{eV}$.

\section{Conclusions}

Using magnetron sputtering, $\mathrm{CuO}$ and $\mathrm{Cu}_{2} \mathrm{O}$ were prepared and the phase and regulation of the optical band gap of the deposited thin films were evaluated. When $\mathrm{Cu}$ metal was used as the target, the oxygen flux rate controlled the crystalline phase of the deposited thin films. When the gas flux ratio of $\mathrm{O}_{2}$ and $\mathrm{Ar}$ was 1:16, $\mathrm{Cu}_{2} \mathrm{O}$ thin films were formed, while a gas flux ratio of $\mathrm{O}_{2}$ and $\mathrm{Ar}$ of $1: 2$ produced $\mathrm{CuO}$ thin films. By optimizing deposition parameters, optical absorption properties of cupric oxide and cuprous oxide thin films were enhanced. The morphologies of the deposited thin films were influenced by heat treatment, and the grain sizes of $\mathrm{Cu}_{2} \mathrm{O}$ thin films increased while the grain boundaries blurred. The $\mathrm{Cu}_{2} \mathrm{O}$ thin films prepared had a critical absorption edge at a wavelength of around $400 \mathrm{~nm}$ and a suitable absorption in the wavelength range of 400-570 nm, while the $\mathrm{CuO}$ thin films showed a good absorption spectrum in the region of 500-900 nm and had a large absorption at wavelengths in the near-IR range. From the UV visible light absorption spectra of $\mathrm{Cu}_{2} \mathrm{O}$ and $\mathrm{CuO}$ thin films, the measured optical band gaps were 2.4 and $1.9 \mathrm{eV}$, respectively. By modulating the parameters for preparation, the optical band gap of the deposited thin films could be adjusted to enhance different optical properties of the copper oxides.

\section{Acknowledgements}

This work was supported by the National Natural Science Foundation of China (No. 61203176) and the Natural Science Foundation of Fujian Province of China (No. 2016J01756 and No. 2013J05098). 


\section{References}

$1 \quad$ N. S. Lewis: Science 315 (2007) 798.

2 H. Anders, B. Gerrit, L. C. Sun, K. Lars, and P. Henrik: Chem. Rev. 110 (2010) 6595.

3 B. O’Regan and M. Gr.atzel: Nature 353 (1991) 737.

4 R. Service: Science 332 (2011) 293.

5 N. S. Xu and S. Ejaz Huq: Mater. Sci. Eng. 48 (2005) 47.

6 K. Ozawa, Y. Oba, and K. Edamotob: Surf. Sci. 603 (2009) 2163.

7 S. Chandrasekaran: Sol. Energy Mater. Sol. Cell 109 (2014) 220.

8 K. P. Muthe, J. C. Vyas, S. N. Narang, D. K. Aswal, S. K. Gupta, R. Pinto, G. P. Kothiyal, and S. B. Sabharwal: Thin Solids Films 324 (1998) 37.

9 S. Kose, E. Ketenci, and V. Bilgin: Curr. Appl. Phys. 12 (2012) 890.

10 M. Kuang, L. T. Tao, and H. Chen: Nanotechnology 26 (2015) 304002.

11 A. H. Jayatissa, K. Guo, and A. C. Jayasuriya: Appl. Surf. Sci. 255 (2009) 9474.

12 T. Minami, Y. Nishi, T. Miyata, and J. Nomoto: Appl. Phys. Express 4 (2011) 062301.

13 C. Arijit, G. Vinay, and K. Sreenivas: Rev. Adv. Mater. Sci. 4 (2003) 75.

14 M. M. Rahman and A. M. Asiri: Sens. Actuators, B 214 (2015) 82.

15 D. Zappa, E. Comini, R. Zamani, J. Arbiol, J. R. Morante, and G. Sberveglieri: Sens. Actuators, B 182 (2013) 7.

16 H. Y. Yan, X. Q. Tian, F. G. Ma, and J. Sun: Sens. Actuators, B 221 (2015) 599.

17 Y. K. Lin, Y. J. Chiang, and Y. J. Hsu: Sens. Actuators, B 204 (2014) 190.

18 V. Andal and G. Buvaneswari: Sens. Actuators, B 155 (2011) 653.

19 W. Siripala, L. D. R. D. Pereraa, K. T. L. De Silvab, J. K. D. S. Jayanettib, and I. M. Dharmadasac: Sol. Energy Mater. Sol. Cell 44 (1996) 251.

20 A. O. Musaa, T. Akomolafeb, and M. J. Carterc: Sol. Energy Mater. Sol. Cell 51 (1998) 305.

21 I. Grozdanov: Mater. Lett. 19 (1994) 281.

22 Y. W. Tang, Z. G. Chen, Z. J. Jia, L. S. Zhang, and J. L. Li: Mater. Lett. 59 (2005) 434. 